\title{
Levels of persistent organochlorine and polychlorinated biphenyls in Nile tilapia (Oreochromis niloticus) from three cage aquaculture farms on the Volta Basin of Ghana: Implications for human health
}

Emmanuel Kaboja Magna ( $\nabla$ egmagna@yahoo.co.uk)

University of Ghana https://orcid.org/0000-0002-7159-7831

Samuel Senyo Koranteng

University of Ghana

Augustine Donkor

University of Ghana

Christopher Gordon

University of Ghana

\section{Research Article}

Keywords: Fish, Contamination, Volta Basin, Risk assessment, Cage aquaculture farm

Posted Date: June 30th, 2021

DOl: https://doi.org/10.21203/rs.3.rs-609853/v1

License: (c) (i) This work is licensed under a Creative Commons Attribution 4.0 International License.

Read Full License 
1 Levels of persistent organochlorine and polychlorinated biphenyls in Nile tilapia (Oreochromis niloticus) from three cage aquaculture farms on the Volta Basin of Ghana: Implications for human health

3 Emmanuel Kaboja Magna ${ }^{1}$, Samuel Senyo Koranteng ${ }^{2}$, Augustine Donkor ${ }^{3}$, Christopher Gordon ${ }^{4}$ 1, 2, 4-Institute for Environment \& Sanitation Studies, University of Ghana, Legon-Accra, Ghana

3-Department of Chemistry, University of Ghana, Legon-Accra, Ghana

Emmanuel Kaboja Magna

Email: egmagna@yahoo.co.uk

\section{Abstract}

Increased agrochemical based agricultural activities along the Volta Basin and aquacultural practices from the cage farms have raised concerns about the potential ecological risk to the aquatic ecosystem. To assess this, caged tilapia samples were analysed for polychlorinated biphenyls (PCBs) and organochlorine pesticide (OCP).Fish samples in acetone/hexane $(2: 1 \mathrm{v} / \mathrm{v})$ solvent medium were sonicated on ultrasonic bath, shaken electronically, cleaned by solidphase extraction and analysed by GC/ECD for OCPs and GC/MS for PCBs. The levels of OCPs reported in the fish ranged; $\mathrm{ND}-2.310 \mu \mathrm{g} / \mathrm{kg}$ (fish farm A), $<\mathrm{LOD}-4.260 \mu \mathrm{g} / \mathrm{kg}$ (fish farm B), $<\mathrm{LOD}-6.109 \mu \mathrm{g} / \mathrm{kg}$ (fish farm C) and $\mathrm{ND}-0.878 \mu \mathrm{g} / \mathrm{kg}$ (control). The highest concentration of $6.109 \mu \mathrm{g} / \mathrm{kg}$ was encountered for $\delta-\mathrm{HCH}$ in the muscles of Tilapia from fish farm $\mathrm{C}$, whiles $p, p^{\prime}$-DDE recorded the lowest in farm A. The levels of the OCPs detected in the cage tilapia were below the MRL proposed by the EU. Six PCBs congeners; PCB 18, PCB 28, PCB 52, PCB 101, PCB153 and PCB 180 were detected in the cage tilapia. The concentrations of the indicator congeners ranged from $0.288 \mathrm{ng} / \mathrm{g}$ to $0.931 \mathrm{ng} / \mathrm{g} \mathrm{dw}, 0.042 \mathrm{ng} / \mathrm{g}$ to $1.321 \mathrm{ng} / \mathrm{g} \mathrm{dw}, 0.260 \mathrm{ng} / \mathrm{g}$ to $10.657 \mathrm{ng} / \mathrm{g}$, and ND-0.298ng/g dw in fish farm A, B, C and control respectively. The highest mean concentrations of PCB $153(8.524 \pm 1.5960 \mathrm{ng} / \mathrm{g})$ was found in farm Estimation of the EDIs and HQs for the pesticides do not present potential health risk to the consumers of the cage tilapia fish from the studied farms.

Keywords: Fish, Contamination, Volta Basin, Risk assessment, Cage aquaculture farm

\section{Introduction}

Organochlorine pesticides (OCPs) and polychlorinated biphenyls (PCBs) are classified as persistent organic pollutants (POPs) by the Stockholm Convention of the United Nations Environment Programme due to their high persistence, toxicity and bioaccumulation to humans and wildlife (WHO 2009). Because of their great persistence and bioaccumulation, they can travel vast distances in the atmosphere and be detected far from where they are not used or manufactured. Their semi-volatility and chemical stability cause them to undergo long-range movement, and therefore, studies have shown their presence in the Arctic and Antarctic regions (Taiwo, 2019).

OCPs and PCBs have been manufactured and applied in many items in recent years, including insecticides, flame retardants, transformer oil, coolants, antifouling agents, and building materials (Mwakalapa et al. 2018). Past industrial and agricultural activities have resulted in the contamination of the soil, air, water and wildlife with the are essential sources of protein (Akoto et al. 2016). 
According to scientific evidence, most pesticide residues are consumed by humans through the food chain (Yohannes et al. 2014). Pesticides in the immediate environment are biomagnified by fish and are ingested by humans. The majority of epidemiological studies indicate that these contaminants may be associated with human cancer and may even affect thyroid hormone levels (e.g., Snedeker, 2001; Beard, 2006; Yohannes et al. 2014). As a result, regulatory bodies have established maximum levels of certain contaminants in food and are constantly reviewing their legislation.

POP pesticides designated under the Stockholm and Rotterdam Conventions for agricultural and public health objectives were banned in developed and developing nations, including Ghana, in 1985. However, due to insufficient restrictions and oversight on the manufacturing, trade, and use of these chemicals, there is evidence of their continued usage in several countries, including Ghana, under various trade names (Darko et al. 2008; Adukumi et al. 2010).

Cultured fish are fed a set amount of food, primarily fish oil and fish meal from various sources, to assure their maximum growth rate and enhance their lipid tissue content (Botaro et al. 2011). Fish meal and fish oil make up around 50-70\% of all ingredients in fish feed. Previous studies (e.g., Easton et al. 2002; Antunes and Gil, 2004; Hites et al. 2004; Navas et al. 2005; Bordajandi et al. 2006; Maule et al. 2007; Kelly et al. 2007; McKee et al. 2008; Serrano et al. 2008; Shaw et al. 2008; Botaro et al. 2011; Grigorakis \&Rigos, 2011) found amounts of DDT, PCBs, and PBDEs in Atlantic salmon diets of 36.66, 10.9, and $36.66 \mathrm{ng}$ g-1, respectively, in their Mediterranean mariculture investigation. These undesired contaminants in farmed high energy Atlantic salmon were caused by fish oils from contaminated pelagic fish species used as a feed element in salmonid diets (Berntssen et al. 2016). McKee et al. identified trace amounts of heptachlor, chlordane, HCB, dieldrin, lindane, and DDT in trout (Oncorhynchus mykiss) muscle and feed samples in 2008. Feed additives such as anti-caking agents, minerals, vitamin combinations, and supplements are also sources of PCBs and OCPs in animal feeds (Kim et al. 2007), and contaminated feed may transfer these toxins to farmed fish (Botaro et al. 2011).

The Volta Basin, which contributes the most to Ghana's inland fisheries, with around $80 \%$ of the overall yield, is home to most large-scale commercial cage culture farms (Amenyogbe et al. 2018). The lake's common fish species include Oreochromis niloticus, Chrysichthys nigrodigitatus, Tilapia zilli, and Clarias gariepinus. In Ghana, these fish have a great commercial value and are eaten fresh, smoked, or salted. Apart from running through numerous agricultural fields and being contaminated by pesticides used for crop protection, the water in the basin is also vulnerable to bad fishing techniques and explosives (Gbeddy et al. 2012; Kuranchie-Mensah et al. 2012). Few studies on POPs such as OCPs and PCBs in Ghana's fresh and marine waters have been conducted (e.g., Gbeddy et al. 2015; Ntow, 2005; Gbeddy et al. 2012; Kuranchie-Mensah et al. 2012; Adu-Kumi et al. 2010; Asante et al. 2013). However, current data on POPs in Ghana's cage aquaculture industry are insufficient to inform government policies and actions regarding POPs. The present study examines the residual levels of PCB and OCP in cagefarmed tilapia from the Volta Basin and the potential health hazards to the general public. 


\section{Materials and methods}

75

76

77

\section{Study area}

The study area comprises the Asuogyaman District in the Eastern region and the Shai Osudoku of the Greater Accra region of Ghana. Figure 1 is a map showing the location of the fish farms marked $(\bullet)$, where samples were collected.

The districts are situated roughly between latitudes $6^{\circ} 34^{\circ} \mathrm{N}$ and $6^{\circ} 10^{\circ} \mathrm{N}$ and longitudes $0^{\circ} 1^{\circ} \mathrm{W}$ and $0^{\circ} 14 \mathrm{E}$. the Basin has one of the largest hydroelectric Dams that generates power to the country and other neighbour countries such as Togo. The Basin also have an inland port which facilitates goods from the southern part Ghana to the northern territories and beyond. Rain-fed agriculture and irrigation are the major economic activities in terms of employment and rural income generation. To boost their crop yield, the farmers use agrochemicals extensively on 83 their farms. As a result, the potential usage of restricted or banned pesticides cannot be ruled out. The area is characterised by a double maximum rainfall pattern, with the major season being from September to November and the minor season occurring from May to July.

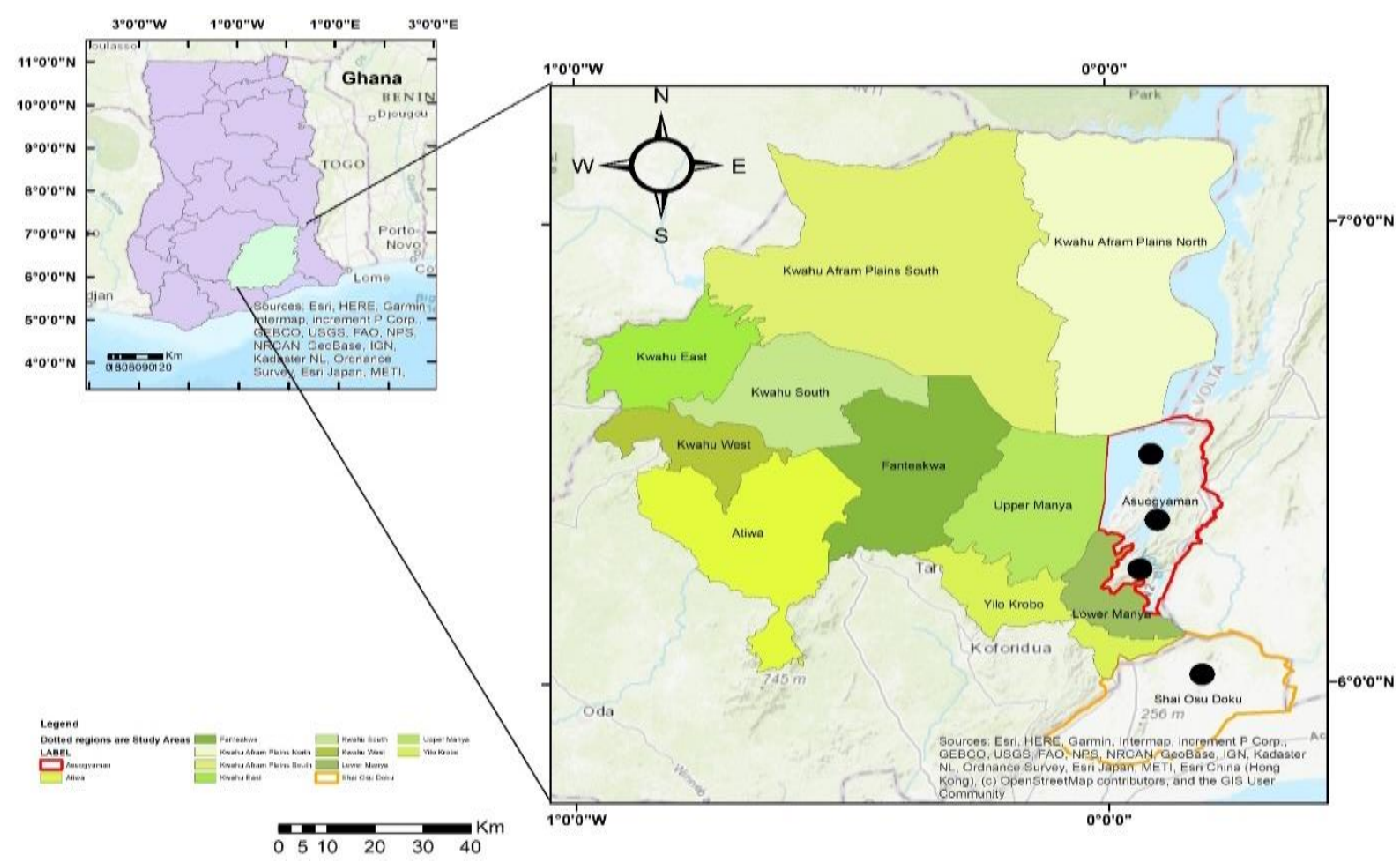

Figure 1: Map of the study area of the Volta Basin, Ghana 
93 Pesticide grade ethyl acetate, distilled water (HPLC grade), acetone, and hexane (both of analytical grades) were

94 supplied by Fisher Scientific (Loughborough, UK), silica gel, and sodium sulphate were purchased from E. Merck

95 (Germany). Sigma-Aldrich Chemicals USA provided disposable solid-phase florisil cartridges $(500 \mathrm{mg} / 6 \mathrm{~mL})$.

96 Dr.Ehrenstofer GmbHm (Germany) provided the certified, high purity (>99.0\%), reference standards of $\alpha-\mathrm{HCH}$,

$97 \gamma-\mathrm{HCH}, \beta-\mathrm{HCH}$, delta-HCH, endrin, heptachlor, aldrin, dieldrin, $o, p^{\prime}-\mathrm{DDT}, p, p^{\prime}-\mathrm{DDT}, p, p^{\prime}-\mathrm{DDD}, o, p^{\prime}-\mathrm{DDD}$,

$98 p, p^{\prime}-\mathrm{DDE}, o, p^{\prime}-\mathrm{DDE}, \alpha$-endosulfan, $\beta$-endosulfan and methoxychlor, and they were kept frozen to prevent them

99 from degrading.

\section{Sample collection and processing}

101 The study included 52 cage tilapias (Oreochromis niloticus) bought from three of the fish farms A= 19, B =16, and

$102 \mathrm{C}=17$ on the Volta Basin. Two of the tilapia fishes were pulled together as a composite working sample.

103 Additionally, twenty (20) samples of wild Oreochromis niloticus were collected as controls from the upstream of the

104 Volta Basin where aquaculture is not practised. All samples of fish were preserved in an airtight bag at $4{ }^{\circ} \mathrm{C}$ and

105 conveyed to the Ghana Atomic Energy Laboratory for further study.

106 The morphometric data of the Tilapia taken were almost the same, while the fillets were removed using a stainless-

107 steel knife. The samples were then washed with deionised water and wrapped in a pre-cleaned aluminium foil and

108 stored at $-20^{\circ} \mathrm{C}$ until extraction. After one week the tilapia samples were taken out of the freezer and defrosted. The

109 muscle tissue was sliced between the dorsal and ventral parts of the fish and chopped into smaller pieces (Gbeddy et

110 al., 2015). The operculum was also removed, which eventually led to the removal of the gills. The samples were

111 homogenised and blended in a Kenwood blender and the content emptied into a dish covered with aluminium foil

112 for the extraction process.

\section{Extraction of fish for Organochlorine pesticides and Polychlorinated biphenyls}

114 The US EPA 3550C method, as described by Solomon (2016) and Adeshina et al. (2019) with a slight modification,

115 was used to extract organochlorine pesticide residues from sediment samples. $10 \mathrm{~g}$ of the grind fish and $5 \mathrm{~g}$ of 116 anhydrous sodium sulphate $\left(\mathrm{Na}_{2} \mathrm{SO}_{4}\right)$ was weighed into an extraction jar. $50 \mathrm{ml}$ acetone and $\mathrm{n}$-hexane $(2: 1 \mathrm{v} / \mathrm{v})$ were

117 thoroughly incorporated into the mixture. The organic extract was filtered through a Whatman filter paper into a

118 well-labelled $250 \mathrm{~mL}$ volumetric flask after 30 minutes of sonication in a Bransonic 220 high-frequency ultrasonic

119 bath at $60^{\circ} \mathrm{C}$. The extraction process was repeated twice, and the combined extracts were concentrated to a volume

120 of $25 \mathrm{ml}$ at a temperature of $45^{\circ} \mathrm{C}$.

121 Sample clean-up

122 In order to avoid interferences, the clean-up system is important for the pesticide residues analysis in a sample.

123 Before the clean-up, silica gel was activated by heating it moderately to about $150^{\circ} \mathrm{C}$ in an air-tight oven. This

124 process removes water content in the gel and increases its adsorptive capacity significantly. The glass separating 125 column $(20 \mathrm{~cm})$ was packed with three layers. The agents were arranged with the activated charcoal at the top, 126 followed by $2 \mathrm{~g}$ of anhydrous granulated $\mathrm{Na}_{2} \mathrm{SO}_{4}$ and the bottom packed with $4 \mathrm{~g}$ of activated silica gel $(90 \%<45$ $127 \mu \mathrm{m}$ ). The activated charcoal removes colouration, the anhydrous $\mathrm{Na}_{2} \mathrm{SO}_{4}$ serves as a demoisturizer and the silica gel, 128 removes co-extractants. Prior to cleaning, $10 \mathrm{~mL}$-hexane was used to condition the columns. The extracts were 
loaded inside the column. The concentrate in the flask was rinsed with $5 \mathrm{ml}$ hexane and added to the column again. The eluate was concentrated to near dryness using a rotary evaporator at a temperature of $45^{\circ} \mathrm{C}$ and picked in $2 \mathrm{ml}$ ethyl acetate vial for Gas Chromatography analysis Determination of the OCPs and PCBs residues

133 A Varian CP-3800 gas chromatograph (Varian Association Inc. USA) with combiPAL auto-sampler and 63Ni electron capture detector was used to analyse the final extracts. VF-5 coated capillary column $(30 \mathrm{~m}+10 \mathrm{~m}$ EZ protection column, $0.25 \mathrm{~mm}$ inner diameter, $0.25 \mathrm{~m}$ film thickness) was employed for the analysis. The temperature of the injector and detector were set at 270 and $300{ }^{\circ} \mathrm{C}$ respectively. The furnace temperature was programmed as follows: $70{ }^{\circ} \mathrm{C}$ held for $2 \mathrm{~min}$, ramp at $25^{\circ} \mathrm{C} / \mathrm{min}$ to $180{ }^{\circ} \mathrm{C}$, held for $1 \mathrm{~min}$ and finally ramp at $5{ }^{\circ} \mathrm{C} / \mathrm{min}$ to $300{ }^{\circ} \mathrm{C}$. In order to compensate for the relative retention times and the response behaviour, the GC conditions and the detector response were determined. $\mathrm{N}$ was used as carrier gas with a flow rate of $1.0 \mathrm{ml} / \mathrm{min}$ and $29 \mathrm{ml} / \mathrm{min}$ as detector additive gas. The injection volume of the GC was $1.0 \mu$. The total running time for one sample was 31.4 $\min$.

142 GC-MS analysis was carried out with Agilent Technologies 6890N (for GC) and 5975 (for MS) in EI mode. The ion source and interface temperatures were $300{ }^{\circ} \mathrm{C}$ and $280{ }^{\circ} \mathrm{C}$ respectively. Chromatographic separation was conducted on a Phenomenex ZB-5MS capillary column $(30 \mathrm{~m} \times 0.25 \mathrm{~mm} \times 0.25 \mu \mathrm{m})$. The gas flow of the carrier was 1.1 $\mathrm{mL} / \mathrm{min}$. The temperature of the injection was $265^{\circ} \mathrm{C}$. The amount of the samples infused was $1 \mu \mathrm{L}$. The temperatures were optimised as follows: The initial oven temperature was maintained for $1 \mathrm{~min}$ at $60^{\circ} \mathrm{C}$, increased to $170{ }^{\circ} \mathrm{C}$ with a $20^{\circ} \mathrm{C} / \mathrm{min}$ ramp, kept for $0.30 \mathrm{~min}$ and then increased by $10^{\circ} \mathrm{C} / \mathrm{min}$ to $310^{\circ} \mathrm{C}$ with a maintaining time of 1.20 min. A mixture of PCB 18, PCB 28, PCB 52, PCB 101, PCB 153, PCB 138, and PCB 180, at a concentration of $10 \mu \mathrm{g} / \mathrm{mL}$ in isooctane from Sigma Aldrich, was injected into the GC $2 \mu \mathrm{L}$ to determine each PCB holding time. By comparing the mass spectra acquired with a database of system mass spectra, the PCBs were identified (NIST, NBS).

\section{Identification and quantification of OCPs and PCBs residues}

153 Residue levels of OCPs and PCBs were quantitatively measured by reference guidelines and residence time estimations. By matching the peak heights of the samples with the respective peak heights of the reference standards for specific concentrations, the residue levels were determined by the external standard procedure. The calculation was performed within the linear range of the detector. To obtain the concentration, the peak areas whose retention times correlated with the standards were subsequently extrapolated to their respective calibration curves. The lowest analyte level that could reliably and consistently provide recovery of $70 \%$ or more from the enriched samples described by Koranteng (2015) was used to determine the LOD for OCPs and PCBs in this paper. Standard OCPs and PCBs mix solutions were serially diluted, and the standard deviation of the signals was measured using the lowest concentration whose recovery from fortified samples was greater than $70 \%$ and also gave a signal to noise ratio of 1:3. The standard deviation (SD) was multiplied by 3 to get the LOD (i.e., SD x $3=$ LOD). The standard deviation for the LOD determination was multiplied by 10 to get the limit of quantification (LOQ) (i.e. SD $\times 10=$ respectively. 


\section{Quality assurance and Quality control}

167 The analytical system integrated quality control and assurance. Measures were taken to guarantee the reliability of the results. All glass apparatus used for research (extraction and cleaning) has been thoroughly rinsed with detergent and tap water. The glassware was cleaned with distilled water before being meticulously cleaned with analytical grade acetone and dried overnight in an oven set at $70^{\circ} \mathrm{C}$. They were taken out of the furnace and placed in dust-free cabinets after cooling. To guarantee the quality of the OCPs and PCB residues, analyses of samples, procedural matrix blanks, and solvent blanks were done in triplicate. Each batch of analytical extracts was analysed

173 simultaneously with procedural recoveries. Furthermore, with each batch of samples, recalibration curves were ran

174 to ensure that the correlation coefficient remained above $\mathrm{r}^{2}>0.995$. Recoveries for internal standards varied from 78 percent to 95 percent for OCPs and 80 percent to 94 percent for PCBs, indicating that the approach used was reproducible.

\section{Statistical analysis}

178 In order to assess the normality of the data, the Kolmogorov-Smirnov (K-S) analysis was performed and at the pvalue less than 0.05 , findings were considered to be statistically significant. Descriptive statistics such as the mean and standard deviation (SD) were used for the levels of OCPs, and PCBs. Ranges were computed for the contaminants. One-way ANOVA was used to test the differences in the contaminants from the fish farms and controls where samples were obtained, with a Tukey's post hoc test.

\section{Risk assessment}

The Estimated Daily Intake (EDI) (mg/kg/day) for the PCBs and OCP residues obtained in the various fish samples was calculated for each age category (Children $<12$ years and adult $\geq 12$ years) using the equation below.

EDI $\left(\mathrm{mgkg}^{-1} \mathrm{day}^{-1}\right)=\frac{(\mathrm{C} \times \mathrm{IR} \times \mathrm{EF} \times \mathrm{ED})}{(\mathrm{BW} \times \mathrm{AT})}$ ..(Equation 1)

Where BW is body weight in $\mathrm{kg}$ AT is the averaging time of exposure in years (life expectancy), $\mathrm{C}$ the concentration of the examined contaminants (OCPs and PCBs) in the fish, EF is the exposure frequency (days/year), ED is the exposure duration (years), and IR is the ingestion rate of Tilapia.

191 The hazard quotient (HQ), which is also the ratio of the EDI to the Acceptable Daily Intake (ADI) or reference

192 doses (Rfd), was used to assess non-carcinogenic risk. Using equation 1 and the Rfd, the HQ for non193 carcinogenic risk is:

If $\mathrm{HQ} \leq 1$ shows no harmful influence on health. However, if the HQ $>1.0$, then there is a potential noncarcinogenic adverse health effect but not demonstrated.

197 The exposure thresholds, according to USEPA (2012) used for health hazard calculations through the ingestion of fish for children and adults, are shown in Table 1. 
Table 1: Parameters of USEPA (2012) for the health risk estimations of OCPs \& PCBs

\begin{tabular}{llll}
\hline Parameters & Units & Children & Adults \\
\hline Bodyweight (BW) & $\mathrm{Kg}$ & 15 & 70 \\
Exposure frequency (EF) & Days/year & 365 & 365 \\
Exposure Duration (ED) & Years & 6 & 30 \\
Ingestion Rate (IR) & mg/day & 200 & 100 \\
Average Time (AT) & Days/yea & & \\
For carcinogenic & & $365 \times 70$ & $366 \times 70$ \\
For non-carcinogenic & & $365 \times \mathrm{ED}$ & $365 \times \mathrm{ED}$ \\
\hline
\end{tabular}

The oral reference dose $(\mathrm{Rfd})(\mu \mathrm{g} / \mathrm{kg} / \mathrm{day})$ of the pesticides were: (delta-HCH $=0.3 ; o, p^{\prime}-\mathrm{DDE}=0.5 ; p, p^{\prime}-\mathrm{DDE}$ $=0.5 ; o, p^{\prime}-\mathrm{DDD}=0.5 ; p, p^{\prime}$-DDT $=0.5 ;$ Heptachlor $=0.5 ;$ Endrin $=0.3 ;$ methoxychlor $=5.0 ;$ PCB $=0.02 ; \alpha-$ endosulfan $=0.05$ (Afful, 2015; Raslan et al. 2018; Omar \& Mahmoud, 2017). The oral reference dose values for the individual indicator PCB congeners were not available in literature. The detected PCBs in the cage fish were therefore summed up and the general Rfd value for PCB, i.e. $0.02 \mu \mathrm{g} / \mathrm{kg} / \mathrm{day}$ (Omar \& Mahmoud, 2017) used for the risk calculations.

210 The target risk of cancer was determined by using the equation:

211 TCR $=$ EDI $\times$ CSF $\cdots$ (Equation 3)

212 Where CSF is the cancer slope factor of the individual pollutant and TCR is the target cancer risk. The CSF for 213 carcinogens; $\delta$ - $\mathrm{HCH}=1.80 \mathrm{mg} / \mathrm{kg} / \mathrm{day}, p, p^{\prime}-\mathrm{DDE}=0.34 \mathrm{mg} / \mathrm{kg} / \mathrm{day}, p, p^{\prime}-\mathrm{DDT}=0.34 \mathrm{mg} / \mathrm{kg} / \mathrm{day}$, heptachlor $=$ $2144.5 \mathrm{mg} / \mathrm{kg} / \mathrm{day}$, endrin $=17.00 \mathrm{mg} / \mathrm{kg} / \mathrm{day}$, and PCBs $=2.00 \mathrm{mg} / \mathrm{kg} / \mathrm{day}$ were obtained from US EPA(2014),

215 Raslan et al. (2018) and Omar \& Mahmoud (2017).The carcinogenic effect regulation was derived by setting 216 the risk from $1.0 \times 10^{-6}$ to $1.0 \times 10^{-4}$ due to lifetime exposure (USEPA 2012).

\section{Results and Discussions}

218 The processed cage tilapia samples were analysed for the residues of 17 different types of OCPs comprising ( $\alpha-$ $219 \mathrm{HCH}, \gamma-\mathrm{HCH}, \beta-\mathrm{HCH}$, delta-HCH, endrin, heptachlor, aldrin, dieldrin, o, $p^{\prime}-\mathrm{DDT}, p, p^{\prime}-\mathrm{DDT}, p, p^{\prime}-\mathrm{DDD}, o, p^{\prime}-$ 220 DDD, $p, p^{\prime}-\mathrm{DDE}, o, p^{\prime}-\mathrm{DDE}, \alpha$-endosulfan, $\beta$-endosulfan and methoxychlor) and 7 PCBs (PCB 18, PCB 28, PCB 221 52, PCB 101, PCB 153, PCB 138 and PCB 180).The results indicate that ten OCPs and six PCBs were detected in 222 the fish samples (Table 2 and Table 3). 
Table 2: Concentrations $(\mu \mathrm{g} / \mathrm{kg})$ of pesticide residues in cage tilapia from fish farms

\begin{tabular}{|c|c|c|c|c|c|c|c|c|}
\hline & \multicolumn{2}{|l|}{ FISH FARM A } & \multicolumn{2}{|c|}{ FISH FARM B } & \multicolumn{2}{|c|}{ FISH FARM C } & \multicolumn{2}{|l|}{ CONTROLS } \\
\hline Pesticides & Mean \pm SD & Range & Mean \pm SD & Range & Mean \pm SD & Range & Mean \pm SD & Range \\
\hline$\delta$-HCH & $0.834 \pm 0.444$ & $<\mathrm{LOD}-1.40$ & $2.078 \pm 1.557$ & $1.00-6.00$ & $6.109 \pm 4.530$ & $0.42-12.00$ & $0.546 \pm 0.093$ & ND- 0.64 \\
\hline$o, p^{\prime}$-DDE & $1.393 \pm 0.427$ & $<\mathrm{LOD}-2.00$ & $1.250 \pm 0.500$ & $<\mathrm{LOD}-2.00$ & $2.828 \pm 2.021$ & $<\mathrm{LOD}-6.01$ & $0.616 \pm 0.151$ & ND -0.88 \\
\hline$p, p^{\prime}$-DDE & $0.455 \pm 0.276$ & $0.26-0.65$ & $<\mathrm{LOD}$ & - & $2.439 \pm 3.338$ & $<\mathrm{LOD}-9.00$ & $0.532 \pm 0.074$ & $\mathrm{ND}-0.62$ \\
\hline$o, p^{\prime}-\mathrm{DDD}$ & $<\mathrm{LOD}$ & - & $4.260 \pm 0.994$ & $3.22-4.36$ & $<\mathrm{LOD}$ & - & - & - \\
\hline$p, p^{\prime}$-DDT & $2.310 \pm 0.438$ & $2.00-2.62$ & 1.22 & $\mathrm{ND}-1.22$ & $1.500 \pm 0.707$ & $<\mathrm{LOD}-2.00$ & - & - \\
\hline$\sum$ DDT & $4.158 \pm 1.451$ & $<$ LOD-2.62 & $6.730 \pm 1.494$ & ND - 4.36 & $6.767 \pm 6.066$ & $<$ LOD -9.00 & $1.148 \pm 0.225$ & ND -0.88 \\
\hline Heptachlor & $2.126 \pm 0.748$ & $1.00-3.42$ & $1.335 \pm 0.670$ & $<\mathrm{LOD}-2.34$ & $2.890 \pm 1.734$ & $<\mathrm{LOD}-6.00$ & $0.878 \pm 0.317$ & $\mathrm{ND}-1.20$ \\
\hline Endrin & ND & - & $2.170 \pm 0.240$ & $<\mathrm{LOD}-2.34$ & $3.080 \pm 2.557$ & $<\mathrm{LOD}-6.00$ & $0.820 \pm 0.298$ & $\mathrm{ND}-1.24$ \\
\hline Methoxychlor & $<\mathrm{LOD}$ & - & $3.171 \pm 1.440$ & $<\mathrm{LOD}-5.00$ & $3.889 \pm 3.343$ & $<\mathrm{LOD}-10.25$ & $0.546 \pm 0.093$ & ND -0.64 \\
\hline$\alpha$-endosulfan & $2.210 \pm 0.790$ & $<\mathrm{LOD}-3.00$ & $2.305 \pm 0.863$ & $<\mathrm{LOD}-3.00$ & $1.860 \pm 1.316$ & $<\mathrm{LOD}-3.00$ & $0.738 \pm 0.295$ & ND -1.12 \\
\hline$\beta$-endosulfan & $1.683 \pm 0.639$ & $1.00-2.41$ & $1.340 \pm 0.570$ & $<\mathrm{LOD}-2.05$ & $0.813 \pm 0.506$ & $<\mathrm{LOD}-1.20$ & $0.520 \pm 0.111$ & $\mathrm{ND}-0.62$ \\
\hline$\sum$ endosulfan & $\begin{array}{l}3.893 \pm 1.429 \\
\text { Load }=11.011\end{array}$ & $<$ LOD -2.41 & $\begin{array}{l}3.645 \pm 1.433 \\
\text { Load }=19.129\end{array}$ & $<$ LOD $-\mathbf{3 . 0 0}$ & $\begin{array}{l}2.673 \pm 1.822 \\
\text { Load }=25.408\end{array}$ & $<$ LOD -3.00 & $\begin{array}{l}1.258 \pm 0.406 \\
\text { Load }=5.196\end{array}$ & ND - 1.12 \\
\hline
\end{tabular}

LOD (Limit of detection), SD-standard deviation, ND-Not detected

226 Table 3: Mean concentrations (ng/g) of indicator PCBs in Tilapia from the cage fish farms

\begin{tabular}{|c|c|c|c|c|c|c|c|c|}
\hline \multirow[b]{2}{*}{ PCBs } & \multicolumn{2}{|l|}{ FISH FARM A } & \multicolumn{2}{|l|}{ FISH FARM B } & \multicolumn{2}{|l|}{ FISH FARM C } & \multicolumn{2}{|l|}{ CONTROLS } \\
\hline & Mean \pm SD & Range & Mean \pm SD & Range & Mean \pm SD & Range & Mean \pm SD & Range \\
\hline PCB 18 & ND & - & $0.300 \pm 0.0048$ & $0.296-0.314$ & $0.801 \pm 0.5640$ & $0.296-2.574$ & $0.163 \pm 0.013$ & $\mathrm{ND}-0.172$ \\
\hline PCB 28 & ND & - & ND & - & $0.360 \pm 0.1252$ & $0.260-0.683$ & ND & - \\
\hline PCB 52 & ND & - & $0.054 \pm 0.0105$ & $0.042-0.061$ & $2.564 \pm 1.2977$ & $1.098-3.435$ & $0.285 \pm 0.154$ & $\mathrm{ND}-0.230$ \\
\hline PCB 101 & ND & - & ND & - & $2.592 \pm 1.4961$ & $1.160-4.345$ & ND & - \\
\hline PCB 153 & $0.494 \pm 0.0021$ & $0.296-0.305$ & $1.807 \pm 0.5142$ & $1.321-0.253$ & $8.524 \pm 1.5960$ & $6.393-10.657$ & ND & - \\
\hline PCB 180 & $0.296 \pm 0.1758$ & $0.288-0.931$ & $1.799 \pm 0.5129$ & $1.113-0.302$ & $5.835 \pm 1.9760$ & $4.112-8.035$ & $0.297 \pm 0.001$ & $\mathrm{ND}-0.298$ \\
\hline$\Sigma$ PCBs & $0.790 \pm 0.1779$ & & $3.960 \pm 1.0424$ & & $20.676 \pm 7.051$ & & $0.745 \pm 0.168$ & \\
\hline
\end{tabular}

ND- Non detected 
The concentrations of organochlorine pesticides generally varied from ND to $2.310 \mu \mathrm{g} / \mathrm{kg}$, <LOD to $4.260 \mu \mathrm{g} / \mathrm{kg}$, $<\mathrm{LOD}$ to $6.109 \mu \mathrm{g} / \mathrm{kg}$ and $\mathrm{ND}$ to $0.878 \mu \mathrm{g} / \mathrm{kg}$ in fish samples from farm $\mathrm{A}, \mathrm{B}, \mathrm{C}$, and controls, respectively. Analyses of the fish samples showed the following order of concentrations: $p, p$-DDT $>\alpha$-endosulfan $>$ heptachlor > $\beta$-endosulfan $>o, p^{\prime}-\mathrm{DDE}>\delta$ - $\mathrm{HCH}>p, p^{\prime}$-DDE; $o, p^{\prime}$-DDD>methoxychlor $>\alpha$-endosulfan $>$ endrin $>\delta$-HCH $>\beta$ endosulfan > heptachlor >o, $p^{\prime}$-DDE $>p, p$-DDT, $\delta$-HCH> methoxychlor > endrin > heptachlor $>o, p^{\prime}-\mathrm{DDE}>p, p^{\prime}-$ DDE $>\alpha$-endosulfan $>p, p$-DDT $>\beta$-endosulfan and heptachlor $>\alpha$-endosulfan $>0, p^{\prime}-\mathrm{DDE}>\delta$-HCH=methoxychlor $>$ $\beta$-endosulfan in Fish Farms A, B, C and controls respectively. Generally, the mean concentration of OCPs recorded in the tissues of the fishes from all the farms ranges ND $-6.109 \mu \mathrm{g} / \mathrm{kg}$. The highest concentration of $6.109 \mu \mathrm{g} / \mathrm{kg}$ was recorded for $\delta$ - $\mathrm{HCH}$ in the muscle tissue of Tilapia in Fish Farm $\mathrm{C}$, while $p$, $p^{\prime}$-DDE recorded the lowest concentration in the muscle tissue of Tilapia in fish farm A.The default Maximum Residue Level (MRL) for any pesticide in fish tissue in the European Union (EU) is $10 \mathrm{~g} / \mathrm{kg}$ (Koranteng, 2015). Accordingly, all OCP residues in the muscle tissues of cage tilapia from fish farms were less than the MRL Regarding DDT metabolites, DDE (total p,p-DDE and o,p-DDE) was the predominant isomer in all farms except Farm A. This was expected, as DDE is more stable than DDT and degrades more slowly when exposed to microbes, heat, and ultraviolet rays (Kafilzadeh, 2015). Additionally, DDE has a longer half-life in fish (approximately 7 years) than p,p-DDT (8 months) (Yahia \& Elsharkawy, 2014). Similarly, the uptake of DDE from the environment in farms B, C, and controls, rather than DDT, indicates that no significant fresh DDT input occurred at those locations. Bioconcentration is dependent on food chain transfer and the feeding habits of individual fish; thus, the higher DDE levels in Farms B, C, and the controls could be attributed to differences in their bioconcentrations. The calculated ratio of p,p'-DDT/total-DDE in Tilapia for Fish Farm A was 1.25. This indicates the introduction of a new contaminated source of technical DDT into Farm A.

250 The concentrations of $\sum$ DDTs in fish muscle samples from Lake Taabo (109.35g/kg) (Roche et al. 2007), River 251 Densu (16.82g/kg) (Afful et al. 2010), and Lake Bosomtwi (8.88g/kg) (Darko et al. 2008) were significantly higher 252 than the reported values from farms A, B, and C. Fish samples collected from Lake Manzala in Egypt (1.89g/kg) 253 (Kamel et al., 2015) and Lake Ziway in Ethiopia (4.15g/kg) (Yohannes et al. 2014) contained significantly less $254 \sum$ DDTs than those from farms A, B, and C used in the study. Jarvinen and Ankley (1999) reported adverse effects 255 on freshwater fish exposed to $\sum \mathrm{DDT}$ at concentrations up to $0.500 \mathrm{~g} / \mathrm{kg} \mathrm{ww}$. According to this argument, the total 256 DDT concentrations detected in adult fish muscle from farms A $(4.158 \mathrm{~g} / \mathrm{kg}), \mathrm{B}(6.730 \mathrm{~g} / \mathrm{kg}), \mathrm{C}(6.767 \mathrm{~g} / \mathrm{kg})$, and controls $(1.148 \mathrm{~g} / \mathrm{kg})$ during the study could impair their normal physiological function and growth rate.

258 Endosulfan is abroad-spectrum insecticide as well as acaricide marketed in Ghana with a trade name thiodan, and is 259 used by many subsistence farmers for crop protection. Low concentration of this compound was observed in all samples. According to Botaro et al. (2011), this contamination can be traced back to the substances used in the production of fish feeds, particularly vegetable oils and meals. The endosulfan- $\alpha / \beta$ isomer ratio for the study ranged between 1.30 and 2.29. This ultimately was not different from the $\alpha / \beta$ ratio reported by Botaro et al. (2011)

263 for Tilapia in Brazil. Relatively higher concentrations of $\alpha$-endosulfan instead of- $\beta$ were anticipated, given the 264 higher concentration of the $\alpha$-endosulfan isomer (70\%) in technical endosulfan mixtures than the $\beta$-isomer. 
Furthermore, due to the faster metabolic rate of $\beta$-isomer in fish compared to $\alpha$-isomer, the level of $\beta$-isomer in fish was much lower(ATSDR 2000). The Eendosulfan concentrations measured in the fish muscle samples from Lake Taabo in Cote d'Ivoire $(0.39 \mu \mathrm{g} / \mathrm{kg})$ (Roche et al. 2007), Ogbesse River in Nigeria $(0.39 \mu \mathrm{g} / \mathrm{kg}$ ) (Ezemonye et al. 2015) and Lake Geriyo in Nigeria $(171.10 \mu \mathrm{g} / \mathrm{kg}$ ) (Shinggu et al. 2015) were higher than those obtained for this study.

Endosulfan is a broad-spectrum insecticide and acaricide that is marketed in Ghana under the trade name thiodan. It is used to protect crops by a large number of subsistence farmers. This compound was found in trace amounts in all samples. Botaro et al. (2011) attribute this contamination to substances used to manufacture fish feeds, particularly vegetable oils and meals. The endosulfan- $\alpha / \beta$ isomer ratio for the study ranged between 1.30 and 2.29. This resulted in a ratio similar to that reported by Botaro et al. (2011) for Tilapia in Brazil. Relatively higher concentrations of $\alpha$-endosulfan instead of- $\beta$ were anticipated, given the higher concentration of the $\alpha$-endosulfan isomer $(70 \%)$ in technical endosulfan mixtures than the $\beta$-isomer. Additionally, because $\beta$-isomer has a faster metabolic rate in fish than $\alpha$-isomer, the level of $\beta$-isomer in fish was significantly lower (ATSDR 2000). $\sum$ Endosulfan concentrations in fish muscle samples from Lake Taabo in Côte d'Ivoire $(0.39 \mathrm{~g} / \mathrm{kg}$ ) (Roche et al. 2007), the Ogbesse River in Nigeria $(0.39 \mathrm{~g} / \mathrm{kg}$ ) (Ezemonye et al. 2015), and Lake Geriyo in Nigeria (171.10g/kg) (Shinggu et al. 2015) were all higher than those obtained in this study.

Additionally, delta-HCH was the only isomer detected, even though gamma-HCH, marketed under the trade name Gammlin 20, was widely used on farms and in animal husbandry in Ghana until 2007 when it was virtually phased out (Kuranchie-Mensah et al. 2012). The mean delta-HCH composition was generally greater in Fish Farm C than in Farm A, at $6.109 \pm 4.550 \mu \mathrm{g} / \mathrm{kg}$ and $0.834 \pm 0.444 \mu \mathrm{g} / \mathrm{kg}$, respectively. The distribution of the delta-HCH isomer across all three farms and controls reflects the historical use of technical mixtures of $\mathrm{HCH}$.

Aldrin and dieldrin were not detected in fish samples, indicating that farmers in the basin do not use them in their farming practises. Heptachlor is a pesticide that disrupts the endocrine system. Adults exposed to heptachlor may experience congenital abnormalities, cancer, particularly hormonal malignancies, a delay in sexual development, and a delay in nervous system development. Heptachlor was detected in all fish samples taken from the farms, indicating that it is less water-soluble. As a result, it accumulates in fish when released into bodies of water. Heptachlor was detected in fish from farms A, B, and C at an average concentration of of $2.126 \mu \mathrm{g} / \mathrm{kg}, 1.335 \mu \mathrm{g} / \mathrm{kg}$ and $2.890 \mu \mathrm{g} / \mathrm{kg}$, respectively. Because heptachlor was most likely converted in vivo via microsomal oxidation to heptachlor epoxide, a more hazardous molecule (US National Academy of Science 1992), the average level of heptachlor was lower in Farm B than in farms A and C.

Methoxychlor concentrations in cage tilapia fish samples (Table 2) were highest in farm C (3.889 $\pm 3.343 \mu \mathrm{g} / \mathrm{kg}$, dry weight); however, methoxychlor concentrations from Farm A were below the detection limit. The elevated methoxychlor levels detected in farm $\mathrm{C}$ fish could be attributed to the fish's high lipid content and current pesticide application on farms closer to the basin (Taiwo et al. 2019).

The allowable limit for methoxychlor, endrin, dieldrin, aldrin, and heptachlor in fish is $0.3 \mathrm{mg} \mathrm{kg}^{-1}(300 \mu \mathrm{g} / \mathrm{kg})$, but the value for DDE, DDT, endosulfan, and DDD is $5 \mathrm{mg} \mathrm{kg}^{-1}(500 \mu \mathrm{g} / \mathrm{kg})$ according to the US Federal Drug 
Administration (Ezemonye et al. 2015). As a result, the levels of identified OCPs were found to be lower than the USFDA levels in all cage Nile tilapia.

The pesticide loads (sum of all detected pesticides) in the Tilapia from the farms were; $11.011 \mu \mathrm{g} / \mathrm{kg}, 19.129 \mu \mathrm{g} / \mathrm{kg}$, $25.408 \mu \mathrm{g} / \mathrm{kg}$ and $5.196 \mu \mathrm{g} / \mathrm{kg}$ in fish farms A, B, C and controls respectively. The highest pesticide load of 25.408 $\mu \mathrm{g} / \mathrm{kg}$ was obtained from fish farm C. This could be due to their high lipid content, making them susceptible to bioaccumulation of more of the organochlorine residue. The findings of the current research are compared in Table 4 with those from other regions of the world, as well as with some from local studies in Ghana. Comparison of the mean OCP residue ranges in muscle tissues from the present study with results from other local studies shows that values from this study were lower. Whereas the highest local OCP concentration range in the muscle of fish $(0.78-94.00 \mu \mathrm{g} / \mathrm{kg})$ was quoted by Koranteng (2015) for fish species from the Afram arm of Volta Lake, that for this study was ND $-6.109 \mu \mathrm{g} / \mathrm{kg}$. Comparing the results,

312 however, to the ranges by some works from other regions of the world; the concentration range for this study was

313 lower. For instance, as shown on Table 4, Abbassy (2018) reported a mean concentration range less than the limit of 314 detection $-6.71 \mu \mathrm{g} / \mathrm{kg}$ for fish species from Rosetta Nile branch estuary in Egypt; Deribe et al. (2011) also recorded 315 a range of $1.86-6.90 \mu \mathrm{g} / \mathrm{kg}$ for species from Lake Koka in Ethiopia; Eqani et al. (2013) reported a mean 316 concentration range $0.75-20 \mu \mathrm{g} / \mathrm{kg}$ for River Chenab in Pakistan while Polder et al., (2014) obtained a mean 317 concentration range $<\mathrm{LOD}-273 \mu \mathrm{g} / \mathrm{kg}$ for OCPs in muscle tissues of Oreochromis niloticus from Lake Victoria,

318 Lake Tanganyika, Lake Nyasa and Lake Babati in Tanzania. Cage aquaculture tilapia from the Ghanaian aquatic 319 ecosystems can therefore generally be considered relatively less contaminated.

320 In Table 4, the current study's findings are compared to those from other parts of the world and some from Ghanaian 321 studies. When the mean OCP residue ranges in muscle tissues from the current study were compared to data from 322 other local investigations, the present study's values were lower.

323 Table 4: Mean concentrations of OCPs residues in fish muscles from local and international studies 324 compared to the present study

\begin{tabular}{|c|c|c|c|c|}
\hline Reference & No. of OCPs & Range $(\mu \mathrm{g} / \mathrm{kg})$ & Location & 325 \\
\hline Studies from Ghana & & & & 326 \\
\hline Afful et al. (2010) & 14 OCPs & $0.3-71.30$ & Densu basin & \\
\hline Adu-Kumi et al. (2010) & 17 OCPs & ND -290.00 & Weija, Bosomtwi and Vol & ta \\
\hline Fianko et al. (2011) & 15 OCPs & $0.51-7.99$ & Densu River basin & 328 \\
\hline Gbeddy et al. (2012) & 15 OCPs & $0.10-17.35$ & Kpando (Volta Lake) & \\
\hline Koranteng (2015) & 3 OCPs & $0.78-94.00$ & Afram Lake arm of Volta & 329 \\
\hline Present study & & & & 330 \\
\hline Fish farm $A$ & $9 O C P s$ & $N D-2.310$ & Volta Basin & \\
\hline Fish farm $B$ & $10 \mathrm{OCPs}$ & $<L O D-4.260$ & Volta Basin & 1 \\
\hline Fish farm $C$ & $10 \mathrm{OCPS}$ & $<L O D-6.109$ & Volta Basin & 332 \\
\hline Studies from other regions & & & & \\
\hline Abbassy (2018) & 7 OCPs & $<$ LOD - 6.71 & Rosetta Nile branch estuar & ry \\
\hline Deribeet al. (2011) & 8 OCPs & $1.86-6.90$ & Lake Koka & 334 \\
\hline Eqaniet al. (2013) & 110CPs & $0.75-20$ & River Chenab & \\
\hline Norliet al. (2011) & 11 OCPs & $1.36-329$ & Superior Lake & 335 \\
\hline Polder et al. (2014) & 10 OCPs & $<\mathrm{LOD}-273$ & $\begin{array}{l}\text { Lake Victoria, L. Tangany } \\
\text { L. Nyasa and L. Babati }\end{array}$ & yiß3,6 \\
\hline
\end{tabular}


While Koranteng (2015) reported the highest local OCP concentration range in fish muscle $(0.78-94.00 \mu \mathrm{g} / \mathrm{kg})$ for fish species from the Afram arm of Volta Lake, the range for this study was ND $-6.109 \mu \mathrm{g} / \mathrm{kg}$. When comparing the results to those of other studies worldwide, the concentration range for this study was lower. For example, Abbassy (2018) reported a mean concentration range less than the limit of detection $-6.71 \mu \mathrm{g} / \mathrm{kg}$ for fish species from Egypt's Rosetta Nile branch estuary, while Deribe et al., (2011) reported a range of $1.86-6.90 \mu \mathrm{g} / \mathrm{kg}$ for species from Ethiopia's Lake Koka. Elsewhere, Eqani et al. (2013) had reported a mean concentration range of0.75 - $20 \mu \mathrm{g} / \mathrm{kg}$ for Pakistan's River Chenab, while Polder et al. (2014) obtained a mean concentration range <LOD - $273 \mu \mathrm{g} / \mathrm{kg}$ for OCPs in muscle tissues of Oreochromis niloticus from Lake Victoria, Lake Tanganyika, Lake Nyasa and Lake Babati in Tanzania. Cage farming tilapia from Ghanaian aquatic environments can thus be deemed less polluted in general.

The study focused on the seven PCB congeners CB-18, CB-28, CB-52, CB-101, CB-138, CB-153, and CB-180, which are considered primary and key indicators of biological loads (Asante et al., 2013). PCBs were found in the fish samples in varying amounts, as shown in Table 3. PCBs were found in large quantities in fish samples from farm C. In fish farm A, B, C, and controls, indicator congener concentrations ranged from $0.288 \mathrm{ng} / \mathrm{g}$ to $0.931 \mathrm{ng} / \mathrm{g}$ dry weight, $0.042 \mathrm{ng} / \mathrm{g}$ to $1.321 \mathrm{ng} / \mathrm{g}$ dry weight, $0.260 \mathrm{ng} / \mathrm{g}$ to $10.657 \mathrm{ng} / \mathrm{g}$, and ND- $0.298 \mathrm{ng} / \mathrm{g}$ dry weight, respectively. The overall PCB concentrations ranged from 0.745 to $20.676 \mathrm{ng} / \mathrm{g}$. Farm C had the highest mean PCB 153 concentrations $(8.5241 .5960 \mathrm{ng} / \mathrm{g})$, followed by PCB $180(5.8351 .9760 \mathrm{ng} / \mathrm{g})$ in the same farm. According to Kampire et al. (2015), the PCB-153's increased persistence in the freshwater ecosystem is due to its extended halflife.

358 Except for the controls, the dominance of PCB-153 and PCB-180 samples in the farms was similar to the dominance of the same contaminants found in other studies (Mwakalapa et al. 2018; Asante et al. 2013; Polder et al. 2016). Higher-chlorinated PCBs (such as PCB 153 and PCB 180) have a higher logKow than lower-chlorinated PCB congeners, which could explain why those congeners are found in higher concentrations in fish. Because there are more unsubstituted ring positions on their biphenyl rings available for metabolic attack, lower chlorinated PCBs have a lower propensity to leave the aqueous environment for organic compartments. Thus, when present in organisms, they are usually more rapidly metabolised than higher chlorinated congeners (Kuranchie-mensah et al. 2011). PCB congeners (PCB-153 and PCB-180) profiles for study farms were comparable to the technical PCB mixture (aroclor 1260), indicating that it was used in Ghana. The level of PCB-153 in farm C fish was similar to that 367 found by Kampire et al. (2015) in South Africa (8.57ng/g).

368 CB-18, CB-28, CB-52, and CB-101, which are less lipophilic lower chlorinated congeners, had a lesser contribution in the fish samples. This could be due to the EPA and other regulatory agencies closely monitoring PCB sources closer to the Basin, such as fire retardants, paint pigments, lubricants, and plasticisers. $\sum$ PCBs concentrations in fish muscle samples from Ghana's Brenya lagoon (150ng/g) (Asante et al. 2013) and Indonesia's Jakarta Bay (400ng/g)

372 (Sudaryanto et al. 2007) were greater than the study's stated levels. Total PCB levels in the Indian Ocean (0.2ng/g 373 and $0.6 \mathrm{ng} / \mathrm{g}$ ), in Tanzania (Mwakalapa et al. 2018) and the Napoleon Gulf in Uganda (0.073ng/g) (Ssebugere et al. 374 2014) were lower than those in the study. Except in Fish Farm A and the controls, where the levels were low, the 
375 total concentration of PCBs in the caged Oreochromis niloticus for the study was much greater than that found by

376 Kuranchie-Mensah et al. (2011) on the same Volta Basin.

378 Risk assessment

379 Table 5 shows the estimated daily intake (EDI) of pesticides such as $\delta$-HCH, $o, p^{\prime}$-DDE, $p, p^{\prime}$-DDE, $o, p^{\prime}$-DDD, $p, p^{\prime}-$

380 DDT, heptachlor, endrin, methoxychlor, $\alpha$-endosulfan, $\beta$-endosulfan and PCB in children and adults from cage 381 tilapia from aquaculture farms in the Volta Basin. The EDIs were much lower than the USEPA's recommended 382 reference dose (Rfd) levels. The implication is that eating the Volta Basin Tilapia investigated does not pose any 383 health risks to children or adults regarding OCPs and PCB contamination.

384 A health hazard measure is the hazard quotient (HQ), which is the ratio of potential chemical exposure to the 385 threshold at which no harmful effects are expected. The Estimated Daily Intake (EDI) is divided by the Reference 386 dosage to get the HQ value. The HQ values of OCPs and PCBs for fish eaten by children and adults from fish farms, 387 as well as the controls, were less than one (1) using the data set from the current study (Table 6). As a result, the 388 consumption of cage tilapia from the Volta Basin farms poses no non-carcinogenic health risk to the population. On 389 the other hand, children had a much higher non-carcinogenic risk than adults. Eating pesticide-contaminated cage 390 fish put consumers at a higher non-carcinogenic risk than eating wild fish (Controls). The pesticide residue found in 391 processed fish samples that has the potential to cause cancer was analysed for carcinogenic risk. 
Table 5: Estimated Daily Intake ( $\mu \mathrm{g} / \mathrm{kg} / \mathrm{day})$ of pesticides in cage fish for Non-carcinogenic risk assessment

\begin{tabular}{|c|c|c|c|c|c|c|c|c|c|}
\hline \multirow[b]{2}{*}{ Pesticides } & \multirow[b]{2}{*}{ Rfd } & \multicolumn{2}{|c|}{ FISH FARM A } & \multicolumn{2}{|c|}{ FISH FARM B } & \multicolumn{2}{|c|}{ FISH FARM D } & \multicolumn{2}{|c|}{ CONTROL } \\
\hline & & Children & $\overline{\text { Adult }}$ & Children & Adult & Children & $\overline{\text { Adult }}$ & Children & Adult 395 \\
\hline$\delta$-HCH & 0.30 & $1.11 \mathrm{E}-05$ & 1.19E-06 & $2.76 \mathrm{E}-05$ & 2.97E-06 & $8.12 \mathrm{E}-05$ & $8.74 \mathrm{E}-06$ & $7.28 \mathrm{E}-06$ & $7.80 \mathrm{E}-07$ \\
\hline$o, p^{\prime}-\mathrm{DDE}$ & 0.50 & $1.85 \mathrm{E}-05$ & $1.99 \mathrm{E}-06$ & $1.66 \mathrm{E}-05$ & $1.79 \mathrm{E}-06$ & $3.76 \mathrm{E}-05$ & 4.04E-06 & $8.21 \mathrm{E}-06$ & 8.80E-0367 \\
\hline$p, p^{\prime}-\mathrm{DDE}$ & 0.50 & $6.05 \mathrm{E}-06$ & $6.51 \mathrm{E}-07$ & NIL & NIL & $3.24 \mathrm{E}-05$ & $3.49 \mathrm{E}-06$ & $7.09 \mathrm{E}-06$ & $7.60 \mathrm{E}-07$ \\
\hline$o, p^{\prime}-\mathrm{DDD}$ & 0.50 & NIL & NIL & $5.67 \mathrm{E}-05$ & $6.09 \mathrm{E}-06$ & NIL & NIL & NIL & NIL دつ০ \\
\hline$p, p^{\prime}$-DDT & 0.50 & 3.07E-05 & $3.30 \mathrm{E}-06$ & $1.62 \mathrm{E}-05$ & $1.74 \mathrm{E}-06$ & $2.00 \mathrm{E}-05$ & $2.15 \mathrm{E}-06$ & NIL & NIL \\
\hline Heptachlor & 0.50 & $2.83 \mathrm{E}-05$ & $3.04 \mathrm{E}-06$ & $1.78 \mathrm{E}-05$ & $1.91 \mathrm{E}-06$ & $3.84 \mathrm{E}-05$ & 4.13E-06 & $1.17 \mathrm{E}-05$ & $1.25 \mathrm{E}-460$ \\
\hline Endrin & 0.30 & NIL & NIL & $2.89 \mathrm{E}-05$ & $3.10 \mathrm{E}-06$ & $4.10 \mathrm{E}-05$ & $4.40 \mathrm{E}-06$ & $1.09 \mathrm{E}-05$ & $1.17 \mathrm{E}-06$ \\
\hline Methoxychlor & 5.00 & NIL & NIL & $4.22 \mathrm{E}-05$ & $4.53 \mathrm{E}-06$ & $5.17 \mathrm{E}-05$ & $5.56 \mathrm{E}-06$ & $7.28 \mathrm{E}-06$ & $7.80 \mathrm{E}-\mathrm{CH}^{\perp}$ \\
\hline$\alpha$-endosulfan & 0.05 & $2.94 \mathrm{E}-05$ & $3.16 \mathrm{E}-06$ & 3.07E-05 & $3.30 \mathrm{E}-06$ & $2.47 \mathrm{E}-05$ & $2.66 \mathrm{E}-06$ & $9.84 \mathrm{E}-06$ & $1.05 \mathrm{E}-06$ \\
\hline$\beta$-endosulfan & NIL & $2.24 \mathrm{E}-05$ & 2.41E-06 & $1.78 \mathrm{E}-05$ & $1.92 \mathrm{E}-06$ & $1.08 \mathrm{E}-05$ & $1.16 \mathrm{E}-06$ & $6.93 \mathrm{E}-06$ & $7.43 \mathrm{E}-403$ \\
\hline PCB & 0.02 & $1.05 \mathrm{E}-05$ & $1.13 \mathrm{E}-06$ & $5.27 \mathrm{E}-05$ & $5.66 \mathrm{E}-06$ & $2.75 \mathrm{E}-04$ & $2.96 \mathrm{E}-05$ & $9.93 \mathrm{E}-06$ & $1.06 \mathrm{E}-06$ \\
\hline
\end{tabular}

$\mathrm{RfD}=$ Reference dose $(\mu \mathrm{g} / \mathrm{kg} / \mathrm{day})$

Table 6: Hazard Quotient of pesticides through consumption of cage tilapia for Non-carcinogenic

\begin{tabular}{|c|c|c|c|c|c|c|c|c|}
\hline \multirow[b]{2}{*}{ Pesticides } & \multicolumn{2}{|c|}{ FISH FARM A } & \multicolumn{2}{|c|}{ FISH FARM B } & \multicolumn{2}{|c|}{ FISH FARM D } & \multicolumn{2}{|c|}{ CONTROL } \\
\hline & Children & Adult & Children & Adult & Children & Adult & Children & Adult \\
\hline$\delta$-HCH & $3.70 \mathrm{E}-05$ & $3.98 \mathrm{E}-06$ & $9.21 \mathrm{E}-05$ & $9.91 \mathrm{E}-06$ & $2.71 \mathrm{E}-04$ & $2.91 \mathrm{E}-05$ & $2.43 \mathrm{E}-05$ & $2.60 \mathrm{E}-06$ \\
\hline$o, p^{\prime}-\mathrm{DDE}$ & $3.71 \mathrm{E}-05$ & 3.98E-06 & 3.33E-05 & $3.58 \mathrm{E}-06$ & 7.53E-05 & 8.09E-06 & $1.64 \mathrm{E}-05$ & $1.76 \mathrm{E}-06$ \\
\hline$p, p^{\prime}-\mathrm{DDE}$ & $1.21 \mathrm{E}-05$ & $1.30 \mathrm{E}-06$ & NIL & NIL & $6.49 \mathrm{E}-05$ & $6.98 \mathrm{E}-06$ & $1.42 \mathrm{E}-05$ & $1.52 \mathrm{E}-06$ \\
\hline$o, p^{\prime}$-DDD & NIL & NIL & $1.13 \mathrm{E}-04$ & $1.22 \mathrm{E}-05$ & NIL & NIL & NIL & NIL \\
\hline$p, p^{\prime}$-DDT & $6.14 \mathrm{E}-05$ & $6.61 \mathrm{E}-06$ & $3.25 \mathrm{E}-05$ & $3.49 \mathrm{E}-06$ & 3.99E-05 & $4.29 \mathrm{E}-06$ & NIL & NIL \\
\hline Heptachlor & $5.66 \mathrm{E}-05$ & $6.08 \mathrm{E}-06$ & $3.55 \mathrm{E}-05$ & $3.81 \mathrm{E}-06$ & 7.69E-05 & 8.27E-06 & 2.34E-05 & $2.50 \mathrm{E}-06$ \\
\hline Endrin & NIL & NIL & $9.62 \mathrm{E}-05$ & $1.03 \mathrm{E}-05$ & $1.37 \mathrm{E}-04$ & $1.47 \mathrm{E}-05$ & 3.63E-05 & $3.90 \mathrm{E}-06$ \\
\hline Methoxychlor & NIL & NIL & 8.43E-06 & $9.07 \mathrm{E}-07$ & $1.03 \mathrm{E}-05$ & $1.11 \mathrm{E}-06$ & $1.46 \mathrm{E}-06$ & $1.56 \mathrm{E}-07$ \\
\hline$\alpha$-endosulfan & $5.88 \mathrm{E}-04$ & $6.32 \mathrm{E}-05$ & $6.13 \mathrm{E}-04$ & $6.59 \mathrm{E}-05$ & $4.95 \mathrm{E}-04$ & 5.32E-05 & $1.97 \mathrm{E}-04$ & $2.10 \mathrm{E}-05$ \\
\hline$\beta$-endosulfan & NIL & NIL & NIL & NIL & NIL & NIL & NIL & NIL \\
\hline PCB & $5.25 \mathrm{E}-04$ & $5.65 \mathrm{E}-05$ & 2.63E-03 & $2.83 \mathrm{E}-04$ & $1.38 \mathrm{E}-02$ & $1.48 \mathrm{E}-03$ & 4.97E-04 & 5.30E-05 \\
\hline
\end{tabular}




\begin{tabular}{|c|c|c|c|c|c|c|c|c|}
\hline \multirow[b]{2}{*}{ Pesticides } & \multicolumn{2}{|c|}{ FISH FARM A } & \multicolumn{2}{|c|}{ FISH FARM B } & \multicolumn{2}{|c|}{ FISH FARM D } & \multicolumn{2}{|c|}{ CONTROL } \\
\hline & Children & Adult & Children & Adult & Children & Adult & Children & Adult \\
\hline$\delta$-HCH & $9.53 \mathrm{E}-07$ & $5.09 \mathrm{E}-07$ & $2.38 \mathrm{E}-06$ & $1.27 \mathrm{E}-06$ & $6.98 \mathrm{E}-06$ & $3.73 \mathrm{E}-06$ & $6.24 \mathrm{E}-07$ & $3.33 \mathrm{E}-07$ \\
\hline$o, p^{\prime}-\mathrm{DDE}$ & $1.59 \mathrm{E}-06$ & $8.51 \mathrm{E}-07$ & $1.43 \mathrm{E}-06$ & $7.63 \mathrm{E}-07$ & 3.23E-06 & $1.73 \mathrm{E}-06$ & 7.04E-07 & 3.76E-07 \\
\hline$p, p^{\prime}-\mathrm{DDE}$ & $5.20 \mathrm{E}-07$ & $2.78 \mathrm{E}-07$ & NIL & NIL & 2.79E-06 & $1.49 \mathrm{E}-06$ & $6.08 \mathrm{E}-07$ & $3.24 \mathrm{E}-07$ \\
\hline$o, p^{\prime}-\mathrm{DDD}$ & NIL & NIL & $4.87 \mathrm{E}-06$ & $2.60 \mathrm{E}-06$ & NIL & NIL & NIL & NIL \\
\hline$p, p^{\prime}$-DDT & $2.64 \mathrm{E}-06$ & $1.41 \mathrm{E}-06$ & $1.39 \mathrm{E}-06$ & 7.45E-07 & 1.71E-06 & $9.16 \mathrm{E}-07$ & NIL & NIL \\
\hline Heptachlor & $2.43 \mathrm{E}-06$ & $1.30 \mathrm{E}-06$ & $1.53 \mathrm{E}-06$ & $8.15 \mathrm{E}-07$ & 3.30E-06 & $1.76 \mathrm{E}-06$ & $1.00 \mathrm{E}-06$ & $5.36 \mathrm{E}-07$ \\
\hline Endrin & NIL & NIL & $2.48 \mathrm{E}-06$ & $1.33 \mathrm{E}-06$ & $3.52 \mathrm{E}-06$ & $1.88 \mathrm{E}-06$ & $9.37 \mathrm{E}-07$ & $5.01 \mathrm{E}-07$ \\
\hline Methoxychlor & NIL & NIL & $3.62 \mathrm{E}-06$ & $1.94 \mathrm{E}-06$ & 4.45E-06 & 2.37E-06 & $6.24 \mathrm{E}-07$ & 3.33E-07 \\
\hline$\alpha$-endosulfan & $2.53 \mathrm{E}-06$ & $1.35 \mathrm{E}-06$ & $2.63 \mathrm{E}-06$ & $1.41 \mathrm{E}-06$ & 2.13E-06 & $1.14 \mathrm{E}-06$ & $8.43 \mathrm{E}-07$ & $4.51 \mathrm{E}-07$ \\
\hline$\beta$-endosulfan & NIL & NIL & NIL & NIL & NIL & NIL & NIL & NIL \\
\hline PCB & $9.03 \mathrm{E}-07$ & $4.82 \mathrm{E}-07$ & 4.53E-06 & $2.42 \mathrm{E}-06$ & $2.36 \mathrm{E}-05$ & $1.26 \mathrm{E}-05$ & $8.51 \mathrm{E}-07$ & $4.55 \mathrm{E}-07$ \\
\hline
\end{tabular}

\begin{tabular}{|c|c|c|c|c|c|c|c|c|c|}
\hline \multirow[b]{2}{*}{ Pesticides } & \multirow[b]{2}{*}{$\mathrm{CSF}(\mu \mathrm{g} / \mathrm{kg} / \mathrm{day})$} & \multicolumn{2}{|c|}{ FISH FARM A } & \multicolumn{2}{|c|}{ FISH FARM B } & \multicolumn{2}{|c|}{ FISH FARM D } & \multicolumn{2}{|c|}{ CONTROL } \\
\hline & & Children & Adult & Children & Adult & Children & Adult & Children & Adult \\
\hline$\delta$-HCH & $1.80 \mathrm{E}-03$ & $1.72 \mathrm{E}-09$ & $9.19 \mathrm{E}-10$ & $4.28 \mathrm{E}-09$ & 2.29E-09 & $1.26 \mathrm{E}-08$ & $6.73 \mathrm{E}-09$ & $1.12 \mathrm{E}-09$ & $5.99 \mathrm{E}-10$ \\
\hline$p, p^{\prime}$-DDE & $3.40 \mathrm{E}-04$ & $1.76 \mathrm{E}-10$ & $9.47 \mathrm{E}-11$ & NIL & NIL & $9.48 \mathrm{E}-10$ & $5.08 \mathrm{E}-10$ & $2.07 \mathrm{E}-10$ & $1.10 \mathrm{E}-10$ \\
\hline$p, p^{\prime}-\mathrm{DDT}$ & $3.40 \mathrm{E}-04$ & $8.98 \mathrm{E}-10$ & $4.81 \mathrm{E}-10$ & $4.74 \mathrm{E}-10$ & $2.54 \mathrm{E}-10$ & $5.83 \mathrm{E}-10$ & $3.12 \mathrm{E}-10$ & NIL & NIL \\
\hline Heptachlor & $4.50 \mathrm{E}-03$ & $1.09 \mathrm{E}-08$ & $5.86 \mathrm{E}-09$ & 6.87E-09 & $3.68 \mathrm{E}-09$ & $1.49 \mathrm{E}-08$ & 7.96E-09 & 4.50E-09 & $2.41 \mathrm{E}-09$ \\
\hline Endrin & $1.70 \mathrm{E}-02$ & NIL & NIL & $4.22 \mathrm{E}-08$ & $2.26 \mathrm{E}-08$ & $5.98 \mathrm{E}-08$ & $3.20 \mathrm{E}-08$ & $1.59 \mathrm{E}-08$ & $8.52 \mathrm{E}-09$ \\
\hline PCB & $2.00 \mathrm{E}-03$ & $1.81 \mathrm{E}-09$ & $9.67 \mathrm{E}-10$ & 9.05E-09 & 4.85E-09 & 4.72E-08 & $2.53 \mathrm{E}-08$ & $1.70 \mathrm{E}-09$ & $9.10 \mathrm{E}-10$ \\
\hline
\end{tabular}


411 Table 7 shows the results of the EDI measurement for carcinogenic risk. The EDIs were significantly lower than the 412 Rfd standards established by the USEPA in 2012. The cancer risk was computed using the computed EDI for 413 carcinogenicity and the cancer slope factors for each pollutant and the results in Table 8. Cancer risk controls 414 specified by the USEPA vary from $1.0 \times 10^{-6}$ to $1.0 \times 10^{-4}$. (USEPA 2012). The study's findings showed that the 415 projected pesticide cancer risks from eating caged tilapia from the Volta Basin were within USEPA restrictions. As 416 a result, OCPs and PCBs in processed fish samples from farms A, B, C, and controls at the time of investigation 417 were unlikely to represent a carcinogenic risk to both young children and adults.

\section{Conclusion}

419 The study discovered a wide variety of PCBs and OCPs residues in the muscle of cage tilapia. The major pesticides found in the fish muscle were DDT metabolites, PCB 153, and PCB 180. Farm C had the highest pesticide load in the samples, implying contamination from many sources. Although most pesticides were present due to past inputs, their residues in the fish muscle tissue were below the EU's suggested MRL. According to US EPA regulations, fish samples from the fish farms investigated in this study do not represent a risk to human eating. As a result, the trend of these pollutants and their ecotoxicological effects on cage tilapia from aquaculture farms must be monitored regularly.

426 Acknowledgements: The authors are grateful to Dr Paul Osei-Fosu, Dr Samuel Lowor and Dr Samuel Afful of 427 Ghana Standard Authority (GSA), Cocoa Research Institute of Ghana (CRIG) and the Ghana Atomic Energy Commission (GAEC) respectively for allowing them access to their laboratories from the extractions stage to the final analyses.

Authors' contributions: EKM proposed the idea, collected the data, analysed and interpreted the data, and wrote the manuscript; SSK, AD and CG revised the manuscript and made important suggestions on the content and study design. All Authors read and approved the final manuscript.

\section{Declarations}

Data availability: The datasets generated during the current study are not publicly available due to the University policy on data restriction until $\mathrm{PhD}$ thesis is completely examined. However, data is available from the corresponding author on reasonable request

Ethical Approval: All laboratory procedures performed in the studies on the cage aquaculture tilapia (Oreochromis niloticus) were approved by the Research Ethical Committee of the University of Ghana

441 Consent to Participate: All authors consent to participate in the publication

442 Consent for Publication: All authors provide consent for publication

443 Conflict of interest: The authors declare no competing interest

444 Funding: No funding was received to assist with the preparation and publication of this manuscript. 


\section{Reference}

448

Abbassy MMS (2018) Distribution pattern of persistent organic pollutants in the aquatic ecosystem at the Rosetta Nile branch estuary into the Mediterranean Sea, North of Delta, Egypt. Marine Pollution Bulletin 131:115-121.https://doi.org/10.1016/j.marpolbul.2018.03.049

Adeshina YA,Solomon A,Ademola AF (2019) Contamination Levels of Organochlorine and Organophosphorous Pesticide Residues in Water and Sediment from River Owena, Nigeria. Current Journal of Applied Science and Technology, 1-11.DOI:10.9734/cjast/2019/v34i230119

Adu-Kumi S, Kawano M, Shiki Y, Yeboah PO, Carboo D, et al. (2010)Organochlorine pesticides (OCPs), dioxinlike polychlorinated biphenyls (dl-PCBs), polychlorinated dibenzo-p-dioxins and polychlorinated dibenzo furans (PCDD/Fs) in edible fish from Lake Volta, Lake Bosumtwi and Weija Lake in Ghana. Chemosphere, 81: 675-684.https://doi.org/10.1016/j.chemosphere.2010.08.018

Afful S (2015) Persistent Organochlorine Pollutants in Lake Bosomtwi and Weija Lake and their potential toxicological health implications. Doctoral dissertation, Kwame Nkrumah University of Science and Technology, Kumasi, Ghana

Afful S, Anim AK, Serfor-ArmahY (2010) Spectrum of organochlorine pesticide residues in fish samples from the Densu Basin. Res J Environ Earth Sci 2: 133-138.

Akoto O, Azuure AA, Adotey KD (2016) Pesticide residues in water, sediment and fish from Tono Reservoir and their health risk implications. SpringerPlus 5:1849.https://doi.org/10.1186/s40064-016$3544-\mathrm{z}$

Amenyogbe E, Chen G, Wang Z, Lin M, Lu X, Atujona D (2018) A Review of Ghana's Aquaculture Industry. $J$ Aquac Res Development 9: 2.DOI: 10.4172/2155-9546.1000545

Antunes P, Gil O (2004) PCB and DDT contamination in cultivated and wild sea bass from Rio Aveiro, Portugal. Chemosphere 54:1503-1507.https://doi.org/10.1016/j.chemosphere.2003.08.029

ATSDR - Agency for Toxic Substances and Disease Registry (2000) Toxicological profile for Endosulfan. US Department of Health and Human Services, Public Health Service, Atlanta, GA.

Beard J (2006)DDTandhumanhealth.Sci.TotalEnviron.355:78-89. https://doi.org/10.1016/j.scitotenv.2005.02.022

Berntssen MH, Sanden M, Hove H, Lie $\varnothing$ (2016) Modelling scenarios on feed-to-fillet transfer of dioxins and dioxin-like PCBs in future feeds to farmed Atlantic salmon (Salmo salar). Chemosphere 163:413-421. https://doi.org/10.1016/j.chemosphere.2016.08.067

Bordajandi LR, Martin I, Abad E, Rivera J, Gonzalez MJ (2006) Organochlorine com-pounds (PCBS, PCDDS and PCDFS) in seafish and seafood from the Spanish Atlantic Southwest Coast. Chemosphere 64:1450-1457. https://doi.org/10.1016/j.chemosphere.2005.12.059

Botaro D, Torres JPM, Malm O, Rebelo MF, Henkelmann B, SchrammKW (2011) Organochlorine pesticides residues in feed and muscle of farmed Nile tilapia from Brazilian fish farms. Food and chemical toxicology49: 2125-2130.https://doi.org/10.1016/j.fct.2011.05.027 
Cox C, Surgan M (2006) Unidentified inert ingredients in pesticides: implications for human and environmental health. Environmental health perspectives 114:1803-1806

Darko G, Akoto O,Oppong C(2008)Persistent organochlorine pesticide residues in fish, sediments and water from Lake Bosomtwi, Ghana. Chemosphere 72:21-24.https://doi.org/10.1016/j.chemosphere.2008.02.052

Deribe E, Rosseland BO, BorgstrømR, Salbu B, Gebremariam Z, et al. (2011)Bioaccumulation of persistent organic pollutants (POPs) in fish species from Lake Koka, Ethiopia: the influence of lipid content and trophic position. Science of the total environment 410:136-145. https://doi.org/10.1016/j.scitotenv.2011.09.008

Easton MDL, Luszniak D, Von der Geest E (2002) Preliminary examination of contaminat loadings in farmed salmon, wild salmon and commercial salmon feed. Chemosphere 46:1053-1074. https://doi.org/10.1016/S0045-6535(01)00136-9

Eqani SAMAS, Malik RN, Cincinelli A, Zhang G, MohammadA, et al.(2013). Uptake of organochlorine pesticides (OCPs) and polychlorinated biphenyls (PCBs) by river water fish: the case of River Chenab. Science of the Total Environment450: 83-91.https://doi.org/10.1016/j.scitotenv.2013.01.052

Ezemonye L, Ogbeide O, Tongo I (2015) Distribution and ecological risk assessment of pesticide residues in surface water, sediment and fish from Ogbesse River, Edo State, Nigeria. J. Environ. Chem. Ecotoxicol, 7: 20-30.https://doi.org/10.5897/JECE2014.0337

Fianko JR, Donkor A, Lowor ST, Yeboah PO (2011) Pesticide residue in water and sedimentfrom the Densu River basin in Ghana. Elixir Pollution 40:5488-5492.

Fu L, Lu X, Tan J, Zhang H, Zhang Y, Wang S, Chen J (2018) Bioaccumulation and human health risks of OCPs and PCBs in freshwater products of Northeast China. Environmental pollution242: 1527-1534. https://doi.org/10.1016/j.envpol.2018.08.046

Gbeddy G, Glover E, Doyi I, Frimpong S, Doamekpor L (2015) Assessment of organochlorine pesticides in water, sediment, African cat fish and Nile tilapia, consumer exposure and human health implications, Volta Lake. Ghana. J Environ Anal Toxicol, 5:297. doi:10.4172/2161-0525.1000297.

Gbeddy G, Yeboah P, Carboo D, Doamekpor L, Afful S, Nartey V,et al. (2012) Organochlorine pesticide residues inAfrican catfish muscle, Nile tilapia muscle and gills from the middle Volta Basin, KpandoTorkor, Ghana and their potential health risks to humans. Elixir Agriculture 49, 9724-9730.

Heinbuch U (1994) Animal Protein Sources for Rural and Urban Populations in Ghana. Program for the Integrated Development of Artisanal Fisheries in West Africa, Cotonou. Animal Protein Sources for Rural and Urban Populations in Ghana. Program for the Integrated Development of Artisanal Fisheries in West Africa, Cotonou, IDAF/WP/58.

Hites RA, Foran JA, Schwager SJ, Knuth BA, Hamilton MC, Carpenter DO (2004) Global assessment of polybrominated diphenyl ethers in farmed and wild salmon. Environmental Science and Technology,38:4945-4949.https://doi.org/10.1021/es049548m

Kafilzadeh F (2015 Assessment of organochlorine pesticide residues in water, sediments and fish from Lake Tashk, Iran. Achievements in the Life Sciences, 9:107-111.https://doi.org/10.1016/j.als.2015.12.003 
Kamel E, Moussa S, Abonorag MA, Konuk M (2015) Occurrence and possible fate of organochlorine pesticide residues at Manzala Lake in Egypt as a model study. Environmental monitoring and assessment, 187:4161. https://doi.org/10.1007/s10661-014-4161-3

Kelly BC, Ikonomou MG, Blair JD, Morin AE, Gobas FAPC (2007) Food web-specific biomagnification of persistent organic pollutants. Science 317:236-239.DOI: 10.1126/science.1138275

Kim M, Kim S, Yun SJ., Kwon JW, Son SW (2007) Evaluation of PCDD/Fs characterisation in animal feed and feed additives. Chemosphere 69:381-386.https://doi.org/10.1016/j.chemosphere.2007.05.025

Koranteng SS (2015). Pesticides in environmental compartments of Afram arm of the Volta Basin in Ghana, University of Ghana (Doctoral thesis)

Kuranchie-Mensah H, Atiemo SM, Palm LMND, Blankson-Arthur S, Tutu Aet al. (2012)Determination of organochlorine pesticide residue in sediment and water from the Densu river basin, Ghana. Chemosphere 86: 286-292.https://doi.org/10.1016/j.chemosphere.2011.10.031

Maule AG, Gannam AL, Davis JW(2007) Chemical contaminants in fish feeds used infederal salmonid hatcheries in the USA. Chemosphere 67:1308-1315.https://doi.org/10.1016/j.chemosphere.2006.11.02

McKee MJ, Kromrey GB, May TW, Orazio CE (2008) Contaminant levels in rainbow trout, Oncorhynchus mykiss, and their diets from Missouri Coldwater Hatcheries. Bull. Environ. Contam. Toxicol. 80:450-454. https://doi.org/10.1007/s00128-008-9374-0

Mwakalapa EB, Mmochi AJ, Müller MHB, Mdegela RH, Lyche JL, et al. (2018)Occurrence and levels of persistent organic pollutants (POPs) in farmed and wild marine fish from Tanzania. A pilot study. Chemosphere 191:438-449.https://doi.org/10.1016/j.chemosphere.2017.09.121

Navas JM, Merino R, Jiménez B, Rivera J, Abad E, et al. (2005) Organochlorine compounds in liver and concentrations of vitellogenin and $17 \beta$-estradiol in plasma of sea bass fed with a commercial or with a natural diet. Aquatic toxicology 75: 306-315.tps://doi.org/10.1016/j.aquatox.2005.07.014

National Academy of Sciences (United States). Committee on Toxicology (1982) An assessment of the health risks of seven pesticides used for termite control. National Academy of Sciences.

Norli HR, Christiansen A, Deribe E (2011) Application of QuEChERS method for extraction of selected persistent organic pollutants in fish tissue and analysis by gas chromatography mass spectrometry. Journal of Chromatography A1218:7234-7241.https://doi.org/10.1016/j.chroma.2011.08.050

Omar WA, Mahmoud HM (2017) Risk assessment of polychlorinated biphenyls (PCBs) and trace metals in River Nile up-and downstream of a densely populated area. Environmental geochemistry and health39: 125-137.https://doi.org/10.1007/s10653-016-9814-4

Onumah EE, Quaye EA, Ahwireng AK, Campion BB (2020) Fish Consumption Behaviour and Perception of Food Security of Low-Income Households in Urban Areas of Ghana.Sustainability12:7932. https://doi.org/10.3390/su12197932

Perugini M, Manera M, Tavoloni T, Lestingi C, Pecorelli I (2013) Temporal trends of PCBs in feed and dietary influence in farmed rainbow trout (Oncorhynchusmykiss). Food chemistry141:2321-2327. https://doi.org/10.1016/j.foodchem.2013.05.062 
Polder A, Müller MB, Brynildsrud OB, De Boer J, Hamers T, et al. (2016)Dioxins, PCBs, chlorinated pesticides and brominated flame retardants in free-range chicken eggs from peri-urban areas in Arusha, Tanzania: levels and implications for human health. Science of the Total Environment551:656667.https://doi.org/10.1016/j.scitotenv.2016.02.021

Polder A, Müller MB, Lyche JL, Mdegela RH, Nonga HE, Mabiki FP (2014) Levels and patterns of persistent organic pollutants (POPs) in Tilapia (Oreochromis sp.) from four different lakes in Tanzania: Geographical differences and implications for human health. Science of the total environment, 488,252-260. https://doi.org/10.1016/j.scitotenv.2014.04.085

Raslan AA, Elbadry S, DarwishWS (2018) Estimation and Human Health Risk Assessment of Organochlorine Pesticides in Raw Milk Marketedin Zagazig City,Egypt. Journal of toxicology, 2018. https://doi.org/10.1155/2018/3821797

Serrano R, Barreda M, Blanes MA (2008) Investigating the presence of organochlorine pesticides and polychlorinated biphenyls in wild and farmed gilthead sea bream (Sparus aurata) from the Western Mediterranean Sea. Mar. Pollut. Bull. 56: 963-972.https://doi.org/10.1016/j.marpolbul.2008.01.014

Shaw SD, Berger ML, Brenner D, Carpenter DO, Chia-Swee Hong CS, Kannan K (2008) Polybrominated diphenyl ethers (PBDEs) in farmed and wild salmon marketed in the Northeastern United States.Chemosphere 71:1422-1431.https://doi.org/10.1016/j.chemosphere.2008.01.030

Shinggu DY, Maitera ON, Barminas JT (2015) Determination of Organochlorine Pesticides Residue in Fish, Water and Sediment in Lake Geriyo Adamawa State Nigeria. International Research Journal of Pure and Applied Chemistry 212-220.DOI:10.9734/IRJPAC/2015/17100

Snedeker SM (2001) Pesticides and breast cancer risk: are view of DDT, DDE, and dieldrin. Environ. Health Perspect.109:35-47.

Solomon A (2016) Determination of organochlorine pesticide residues in water and sediment samples from selected areas of River llaje, Nigeria. Amer. Chem. Sci. J 11: 1- 6. DOI:10.9734/ACSJ/2016/22274

Ssebugere P, Sillanpää M, Kiremire BT, Kasozi GN, Wang P, Sojinu SO, et al. (2014)Polychlorinated biphenyls and hexachlorocyclohexanes in sediments and fish species from the Napoleon Gulf of Lake Victoria, Uganda. Science of the Total Environment 481: 55-60.https://doi.org/10.1016/j.scitotenv.2014.02.039

Sudaryanto A, Monirith I, Kajiwara N, Takahashi S, Hartono P, Omori K, et al. (2007) Levels and distribution of organochlorinesin fish from Indonesia.Environment international, 33:750-758. https://doi.org/10.1016/j.envint.2007.02.009

Taiwo AM (2019) A review of environmental and health effects of organochlorine pesticides residues in Africa. Chemosphere 220: 1126-1140.https://doi.org/10.1016/j.chemosphere.2019.01.001

World Health Organization. (2009) Children's Health and the Environment. WHO Training Package for the Health Sector-World Health Organization

Yahia D, Elsharkawy EE (2014) Multi pesticide and PCB residues in Nile Tilapia and catfish in Assiut city, Egypt. Science of the total environment 466:306-314.https://doi.org/10.1016/j.scitotenv.2013.07.002

Yohannes YB, Ikenaka Y, Saengtienchai A, Watanabe KP, Nakayama SM, Ishizuka M (2014)Concentrations and human health risk assessment of organochlorine pesticides in edible fish species from a Rift Valley 
lake-LakeZiway,Ethiopia.Ecotoxicology and environmental safety106:95-101.

https://doi.org/10.1016/j.ecoenv.2014.04.014 